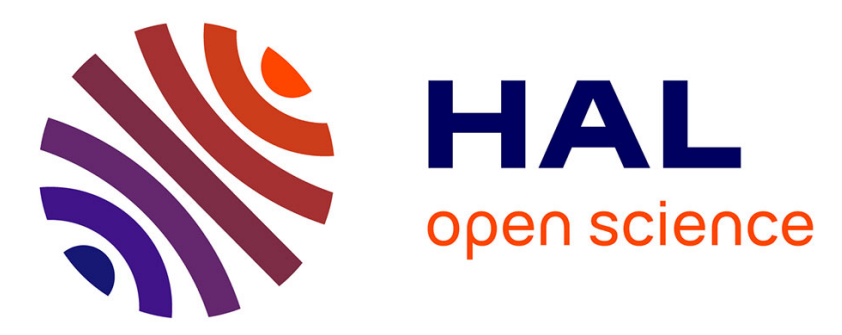

\title{
Fatal tiger shark, Galeocerdo cuvier attack in New Caledonia erroneously ascribed to great white shark, Carcharodon carcharias
}

\author{
Philippe Tirard, Claude Maillaud, Philippe Borsa
}

\section{To cite this version:}

Philippe Tirard, Claude Maillaud, Philippe Borsa. Fatal tiger shark, Galeocerdo cuvier attack in New Caledonia erroneously ascribed to great white shark, Carcharodon carcharias. Journal of Forensic and Legal Medicine, 2015, 33, pp.68-70. 10.1016/j.jflm.2015.04.011 . ird-01260390

\author{
HAL Id: ird-01260390 \\ https://hal.ird.fr/ird-01260390
}

Submitted on 22 Jan 2016

HAL is a multi-disciplinary open access archive for the deposit and dissemination of scientific research documents, whether they are published or not. The documents may come from teaching and research institutions in France or abroad, or from public or private research centers.
L'archive ouverte pluridisciplinaire HAL, est destinée au dépôt et à la diffusion de documents scientifiques de niveau recherche, publiés ou non, émanant des établissements d'enseignement et de recherche français ou étrangers, des laboratoires publics ou privés. 
To be cited as:

Tirard P., Maillaud C., Borsa P. 2015. - Fatal tiger shark, Galeocerdo cuvier attack in New Caledonia erroneously ascribed to great white shark, Carcharodon carcharias. Journal of Forensic and Legal

Medicine 3, 68-70.

Fatal tiger shark, Galeocerdo cuvier attack in New Caledonia erroneously ascribed to great white shark, Carcharodon carcharias

Philippe Tirard a, Claude Maillaud b, Philippe Borsa a,*

${ }^{a}$ Institut de recherche pour le développement, Nouméa, New Caledonia

b Collectif des médecins judiciaires de Nouvelle-Calédonie/Forensic Medical Board of New

Caledonia, Nouméa, New Caledonia

${ }^{*}$ Corresponding author. Institut de recherche pour le développement, UMR 250 eMtroPI, BP A5, 98848 Nouméa, New Caledonia.

Tel.: +62 81237453473 (mobile).

E-mail address: philippe.borsa@ird.fr (P. Borsa).

A B S T R A C T

To understand the causes and patterns of shark attacks on humans, accurate identification of the shark species involved is necessary. Often, the only reliable evidence for this comes from the characteristics of the wounds exhibited by the victim. The present case report is intended as a reappraisal of the Luengoni, 2007 case (International Shark Attack File no. 4299) where a single shark bite provoked the death of a swimmer by haemorrhagic shock. Our examination of the wounds on the body of the victim, here documented by so-far unpublished photographic evidence, determined that the shark possessed large and homodontous jaws. This demonstrates that the attacker was a tiger shark, not a great white shark as previously published.

Keywords: shark attack; wound; misidentification; ISAF; New Caledonia 


\section{Introduction}

New Caledonia's shark fauna has at least 48 species. ${ }^{1}$ This list includes several large species recognized as dangerous to humans, namely: the bull shark, Carcharbinus leucas, the tiger shark, Galeocerdo cuvier, and the great white shark, Carcharodon carcharias. ${ }^{2,3}$ There is widespread admission that dangerous encounters of sharks by humans in a recreational context have increased in New Caledonia in recent years, ${ }^{3,4}$ as in other regions. ${ }^{5,6} \mathrm{~A}$ possible explanation of this trend might well be that human frequentation of the New Caledonian reef and lagoon also increases from year to year. ${ }^{7}$ So far, eight fatal shark attacks have been reported from New Caledonia. ${ }^{3,4,8}$ Three of these attacks have been recorded in the International Shark Attack File (ISAF) of the Florida Museum of Natural History, Gainesville, under numbers c3214, 4299 and 4522. The description of case no. 4299 has been published previously. ${ }^{9}$ The authors, E. Clua and B. Séret, ascribed the attack to the great white shark, Carcharodon carcharias, ${ }^{9}$ but this interpretation differs from other accounts. ${ }^{3,4,10}$ As explained in their paper, ${ }^{9}$ E. Clua and B. Séret acknowledged that their description was based on interviews of witnesses, a police report, a death certificate and some photographs. At the date of writing, case no. 4299 is still deemed 'data insufficient' (B. Gillett, ISAF, pers. comm.). It is only under the condition of accurate identification and account of the circumstances of the attack for each entry in the ISAF database, that reliable information can then be extracted for meaningful expost facto analysis.

The identification and the estimated size of the shark species involved in an attack should rely on objective information. Ideally, the shark, or a good photograph of it, should be identified by a shark specialist. Teeth embedded in the victim or in surrounding objects may also be diagnostic. However, in most cases, forensic identification can only rely on the aspect of the bite damage on the victim. Other information, for instance shark behaviour as reported by witness, has been used to identify the shark to species: ${ }^{9}$ this has proven unreliable, as we will demonstrate in this paper. The present case report is intended as a reappraisal of the Luengoni, 2007 case (ISAF no. 4299).

\section{Case reappraisal}

Detailed accounts of the attack, which took place in Luengoni (Lifou Island, New Caledonia) on 30 September 2007, have been written.,9 The wound was ascribed to "a single large bite with a maximum length of about $40 \mathrm{~cm}$ ". ${ }^{9}$ Disputable points are enumerated in the following. It was reported "that the teeth did not form a continuous cutting edge but instead were separated by more or less wide spaces"; 9 also, the shark had been reported to "jump out of the water" at the moment of the attack, ${ }^{9}$ prompting authors E. Clua and B. Séret to identify the attacker as a great white shark, a shark species that seasonally occurs in New Caledonian waters. ${ }^{7}$ These authors reported that the "femur bone [was] broken at the level of the hip". 9 The wound on the inner thigh was described as "broadly curved and present[ing] clear cut sections (made by large flat teeth) separated by small ragged pieces of skin/flesh (indicating that the teeth did not form a continuous cutting edge but instead were separated by more or less wide spaces)". ${ }^{9}$ Furthermore, the outer part of the bite was described as: "broadly curved and show[ing] similar aligned flat sections separated by small rags of skin/flesh, but somewhat shredded" 9 although no photographic evidence was provided by the authors to support the latter claim and they did not carry out any examination of the body of the victim. The authors also recalled that the single bite inflicted on the victim was a tactic known from great white shark ('bite-and-spit' behaviour) and claimed that "a tiger shark would not have released its mouth contents but would have swallowed it instead". 9 
Two of us (PT, CM) examined the body of the victim on 03 October 2007, soon after it had been transferred to the mortuary in Nouméa. We here provide in Supplementary Material highresolution photographs of the wound, taken by PT. The outer part of the wound is here presented in picture for the first time (Fig. 1). The diameter of the bite, measured by us, was $38 \mathrm{~cm}$ and the bite circumference, deduced from the diameter by assuming a circular shape of the jaw, was 59.7 $\mathrm{cm}$. In contrast with E. Clua and B. Séret's report, ${ }^{9}$ we observed that the femur was neatly cut below trochanter minor, as if it had been sawed, not actually broken. We also observed that the edge of the wound was continuous and no wide spaces between teeth were obvious (as evident also from Figure no. 3 of Reference 9, though contrary to the interpretation provided in it). Moreover, the description of the outer part of the wound as presented previously ${ }^{9}$ was not correct, as actually a single clear cut was present without shredding (Fig. 1). Hence, both the outer and inner sides of the wound showed similarly continuous cuts with a well-defined edge. This hitherto neglected but crucial information indicates that the attacking shark had homodontous jaws, which excludes the great white shark as a possible attacker as explained in the following. ${ }^{4}$ Of the three species capable of a large bite of this size, both the great white shark and the bull shark possess markedly heterodontous jaws.4,11 On their dorsal side, wounds inflicted by great white sharks are clear-cut and quasi-circular while their ventral side is characterized by deep gashes and shredding, as observed on the body of elephant seals (Mirounga angustirostris) bitten by great white sharks on the coast of California. ${ }^{12}$ This, clearly, was not observed on the Luengoni victim's body. The only shark with homodontous jaws able to inflict a large, symmetrical bite such as that observed on the Luengoni victim is the tiger shark (Galeocerdo cuvier). ${ }^{4}$ Wounds inflicted by tiger sharks are indeed symmetrical, as observed on the body of Nari, a bottlenose dolphin (Tursiops aduncus) bitten by a tiger shark off Moreton Island, Australia. ${ }^{13}$ In addition, a tiger shark's tooth has a shape similar to that of a can-opener and its edges are strongly serrated:4,12 these features obviously serve the purpose of sawing through hard material, like turtle shell, dolphin tailstock or whale skull and bones, ${ }^{14-17}$ thus explaining the regular aspect of the section of the femur of the victim.

E. Clua and B. Seret's report ${ }^{9}$ partially relied on a second-hand, incomplete set of photographs lacking the depiction of the posterior part of the wound. In contrast, the present interpretations primarily relied on external examination of the body of the victim. Photographs are here presented to illustrate our de visu observations and not as primary evidence. Some of the additional information presented in Reference 9 is dubious. For instance, the purported observation of the "shark jumping out of the water to reach the victim"9 (a well-known behaviour in great white shark) ${ }^{18,19}$ was not mentioned in the police interview of the main witness, ${ }^{20}$ who subsequently confirmed to us that the declaration she made to the police was accurate and complete. Moreover, the water depth at the site of the attack $(2.50 \mathrm{~m})$ is unlikely to be sufficient for a large shark to gain sufficient momentum to be able to project itself out of the water. ${ }^{18,19}$ Therefore, there was actually no evidence of even the possibility of leaping behaviour in the Luengoni shark. The 'bite and-spit' or 'grab-release' hypothesis, which has been initially proposed to explain the predatory behaviour of great white sharks on marine mammals and turtles, ${ }^{21,22}$ is a tactic also observed or inferred for tiger sharks preying on dolphins.14,16 In one instance, it was inferred that the tiger shark first severed the tailstock of a juvenile bottlenose dolphin (Tursiops sp.) before resuming its attack by removing a chunk of its belly. ${ }^{16}$ In another case, a tiger shark that followed a group of swimming pantropical spotted dolphins (Stenella attenuata) swiftly inflicted a single powerful bite to one dolphin of the pod, severing its tail and causing its death by either haemorrhagic shock or drowning (or both). ${ }^{14}$ 
Lastly, the qualification of the attack as "unprovoked" needs to be re-evaluated, since it has been established that the very days before the attack, a traditional wedding ceremony had taken place in Luengoni village, and that carcasses and offal of pigs, goats, poultry and fish had been disposed off from the shore of Luengoni Bay. ${ }^{3}$

\section{Conclusion}

Behavioural aspects of the Luengoni shark attack are reminiscent of a type of predatory behaviour that has been documented in both tiger sharks and great white sharks. Therefore, behavioural evidence was uninformative and the only diagnostic, first-hand information to be used in the Luengoni case was the characteristics of the wound on the body of the victim. The diagnostic features of the wound were its large size and its dorso-ventral symmetry, indicating homodontous jaws. These two features combined clearly designate the tiger shark as the only possible attacker in this case.

\section{Appendix A. Supplementary data}

Supplementary data related to this article can be found at http://dx.doi.org/10.1016/j.jflm.2015.xx.xxx 


\section{References}

1. Fricke R, Kulbicki M, Wantiez L. Checklist of the fishes of New Caledonia, and their distribution in the Southwest Pacific Ocean (Pisces). Stuttg Beitr Naturk A, Neue Ser 2011; 4: 341 63.

2. Hutchins B, Swainston R. Sea fishes of southern Australia. Perth: Swainston Publishing; 1986: 180 p.

3. Maillaud C, Tirard P, Van Grevelynghe G, Sebat C, Durand F. Attaques de requins en NouvelleCalédonie. J Eur Urgences 2009; 22: 33-7.

4. Tirard P. Les requins du Caillou. Nouméa: Philippe Tirard; 2011: 280 p.

5. West JG. Changing patterns of shark attacks in Australian waters. Mar Freshw Res 2011; 62: 74454.

6. Werbrouck A, Van Grevelynghe G, Landron F, Charlier P, Loire C, Gauthier C. Expertise médicolégale des victimes d'attaques et de morsures de requins à la Réunion. Rev Méd Légale 2014; 5: 110-21.

7. Tirard P, Manning MJ, Jollit I, Duffy C, Borsa P. Records of great white shark (Carcharodon carcharias) in New Caledonian waters. Pac Sci 2010; 64: 567-576.

8. Anonymous. Attaque mortelle de requin à Koumac. Nouv Calédoniennes 2011; 12079.

9. Clua E, Séret B. Unprovoked fatal shark attack in Lifou Island (Loyalty Islands, New Caledonia, South Pacific) by a great white shark, Carcharodon carcharias. Am J Forensic Med Pathol 2010; 31: 281-286.

10. Lepot H, Larue P. Attaques de requins : gare aux tigres! Nouv Calédoniennes 2007; 11015: 2.

11. Laboute P, Grandperrin R. Poissons de Nouvelle-Calédonie. Nouméa: Catherine Ledru; 2000.

12. Long D. The great white shark exhibition. University of California Museum of Paleontology, Berkeley 2015; http://www.ucmp.berkeley.edu/vertebrates/Doug/shark.html.

13. Zasloff M. Observations on the remarkable (and mysterious) wound-healing process of the bottlenose dolphin. J Investigative Dermatol 2011; 131: 2503-05.

14. Mann J, Barnett H. Lethal tiger shark (Galeocerdo cuvier) attack on bottlenose dolphin (Tursiops sp.) calf: defense and reactions by the mother. Mar Mamm Sci 1999; 15: 568-75.

15. Simpfendorfer CA, Goodreid AB, McAuley RB. Size, sex and geographic variation in the diet of the tiger shark, Galeocerdo cuvier, from Western Australian waters. Env Biol Fishes 2001; 61: 37-46.

16. Maldini D. Evidence of predation by a tiger shark (Galeocerdo cuvier) on a spotted dolphin (Stenella attenuata) off O'ahu, Hawai'i. Aquat Mamm 2003; 29: 84-7.

17. Borsa P, Hoarau G. A pygmy blue whale (Cetacea: Balaenopteridae) in the inshore waters of New Caledonia. Pac Sci 2004; 58: 579-84.

18. Martin RA, Hammerschlag N, Collier RS, Fallows C. Predatory behaviour of white sharks (Carcharodon carcharias) at Seal Island, South Africa. J Mar Biol Assoc UK 2005; 85: 1121-35.

19. Klimley AP, Pyle P, Anderson SD. The behavior of white sharks and their pinniped prey during predatory attacks. In: Klimley AP, Ainley DG, editors. Great white sharks: the biology of Carcharodon carcharias, San Diego: Academic Press; 1996, p. 175-91.

20. Pech-Bourg A. Procédure de découverte de cadavre: procès-verbal de transport, constatations et mesures prises. PV Gendarmerie Natl, Nouméa Iles Loyauté, Brig Wé-Lifou 2007; 631/07: 1-19.

21. Tricas TC, McCosker JE. Predatory behaviour of the white shark (Cacharodon carcharias), with notes on its biology. Proc Calif Acad Sci 1984; 43: 221-38.

22. Fergusson IK, Compagno LJV, Marks MA. Predation by white sharks Carcharodon carcharias (Chondrichthyes: Lamnidae) upon chelonians, with new records from the Mediterranean Sea and 
a first record of the ocean sunfish Mola mola (Osteichthyes: Molidae) as stomach contents. Env Biol Fishes 2000; 58: 447-53. 


\section{CAPTION TO FIGURE}

Figure 1. Photograph of the wound on the dorsal side of the victim's right thigh (PT).

Photographs of the wound on the inner side of the thigh have been presented previously. ${ }^{9}$ Highresolution versions of these photographs can be found in the Supplementary Material to this article (Appendix A). 
Figure

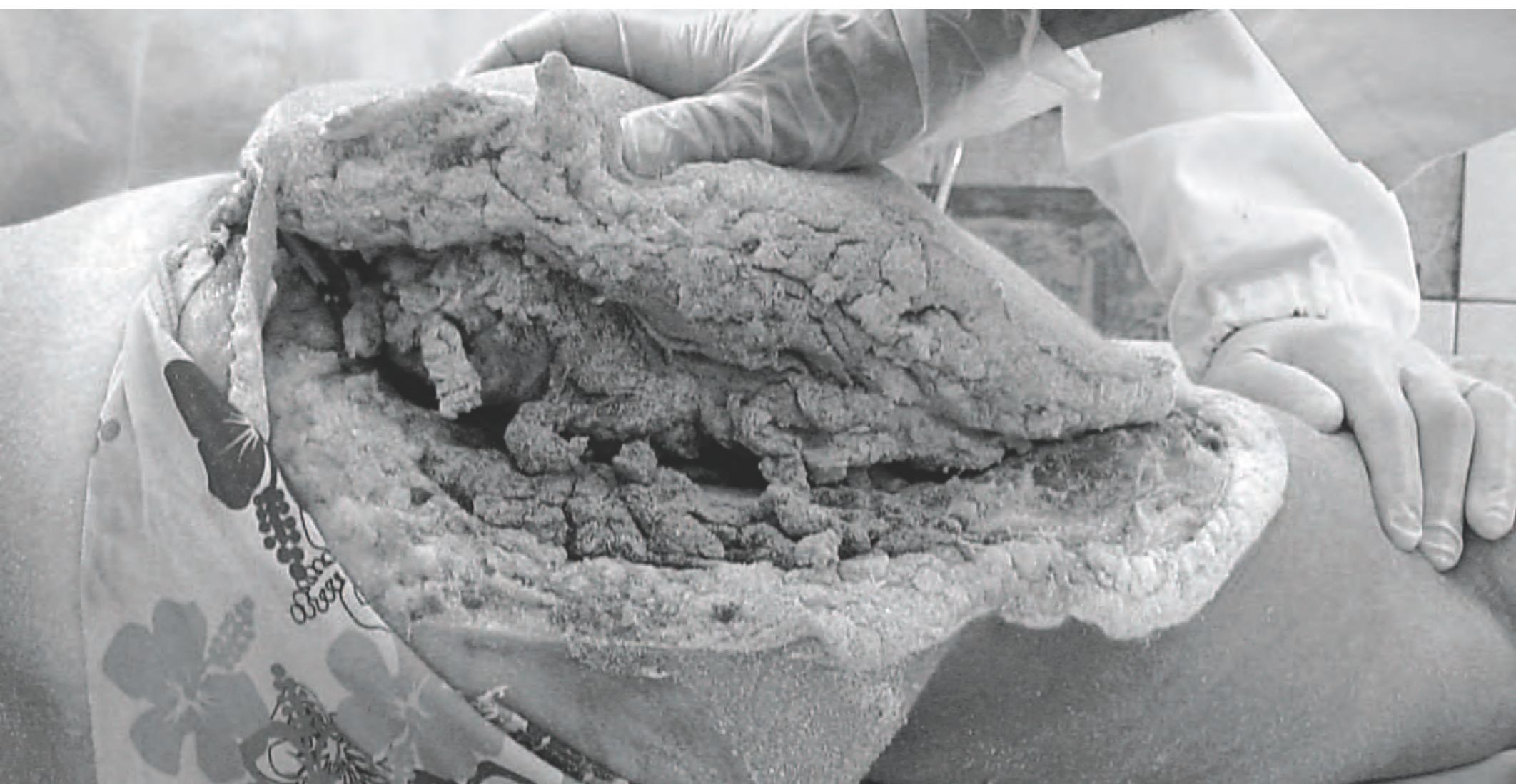


Supplementary Material to "Fatal tiger shark (Galeocerdo cuvier) attack in New Caledonia

erroneously ascribed to great white shark. (Carcharodon carcharias)" by P. Tirard, C. Maillaud and P. Borsa.

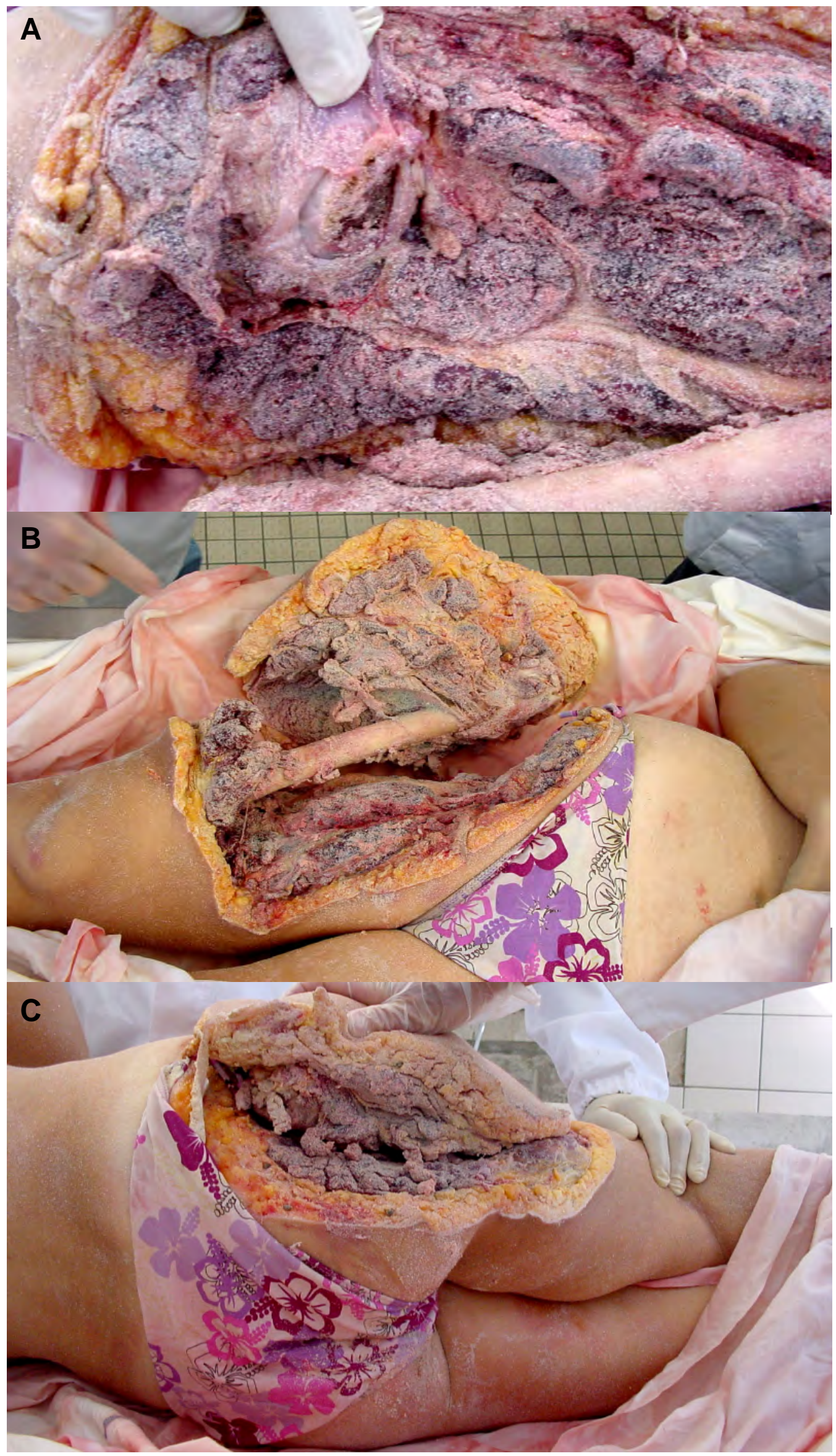

Fig. S1 Aspects of the wound exhibited by the victim of the tiger shark attack at Luengoni, 30 September 2007. Photographs taken by PT at Nouméa mortuary, 03 October 2007. A Interior of wound showing section of femur. B Ventral side of wound. C Dorsal side of wound. 